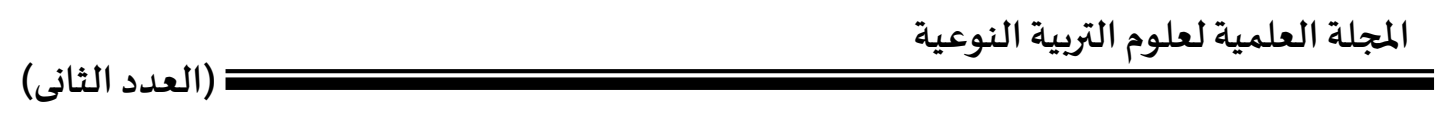

\title{
Biological studies for the effect of Echinacea, Dates and Black seeds for liver dysfunction
}

\author{
Sahar, O. EL-Shafiy; Nehad ,R. EL-Tahan and Asmaa, S. Abo Sena. \\ Nutrition and Food Science Dept., Home Economics Faculty, Menoufiya \\ University, Egypt.
}

\begin{abstract}
The present study was investigated to study the effects ofCone Flowers (Echinacea Purpurea), Black seeds(Nigella sativa) and Dates palm ( Phoenix Dactyliferous, $\boldsymbol{L}$ ) on $\mathrm{CCl}_{4}$ induced hepatotoxicityin rats . Thirty six male albino rats were divided into (6) groups (6) rats in each group. Two groups were as controls, one fed on basal diet onlyas a negative controland the other one fedonbasal diet afterinjection with $\mathrm{CCl}_{4}$ as a positive control.The othergroups were injected by $\mathrm{CCl}_{4}$ thenreceivedbasal diet containingEchinacea purpurea,Nigella sativa, anddates palm at the level of $10 \%$ and $15 \%$ mixture of the tested plant and herbs.Liver damage wasassessedby estimation of plasma concentration of enzymes activities ofaspartateamino transferees (AST), alanineamino transferees (ALT),lipid fraction (total cholesterol and triglyceride), cholesterol fraction (HDL-c, LDL-c, VLDL-c), Uricacid, Urea nitrogen and glucose. Results showedan improvement in case of tested plant and herbsmixture followed by Nigella sativa, Echinacea purpureaanddates palmfor the above parameters. So, this study concluded that $\mathrm{CCl}_{4}$ induced liver damage in rats can be ameliorated by administration of $15 \%$ Nigella sativa, Echinacea purpureaanddates palm.
\end{abstract}

Key words: Nigella sativa, Echinacea purpurea ,Dates palm, liver damage cholesterol fraction- glucose. 
در اسات بيولوجية لتأثير الاشينسيا وحبة البركة والتمر علي الخلل الوظيفي للكبد

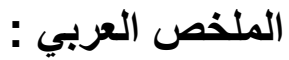

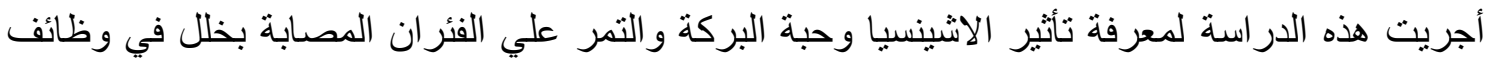

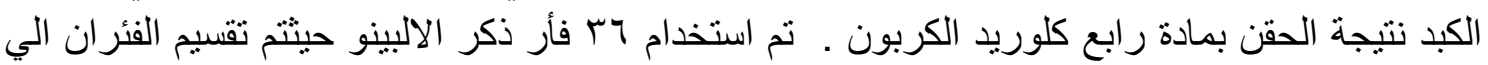

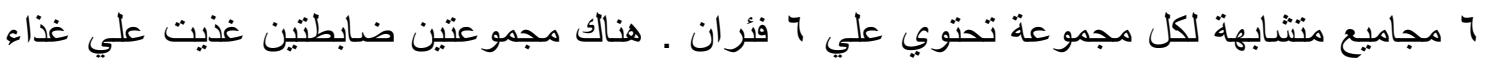

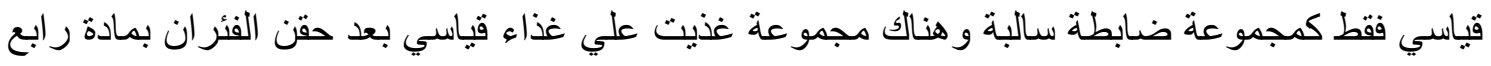

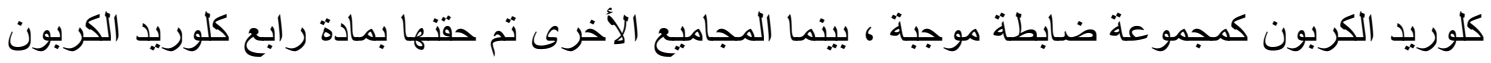

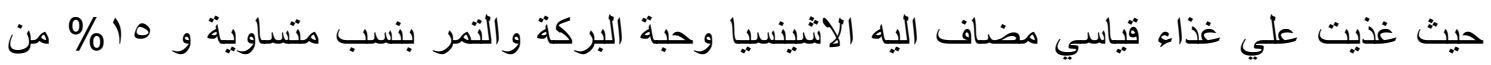

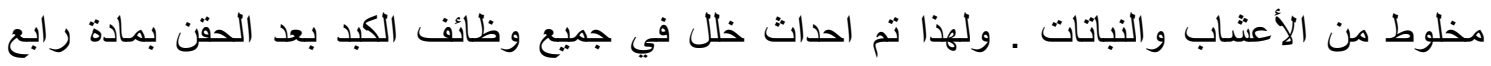

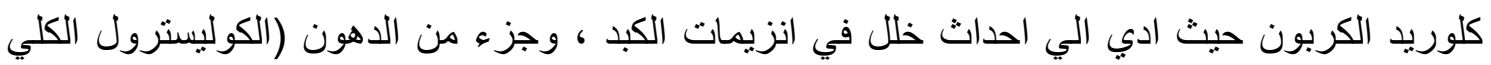

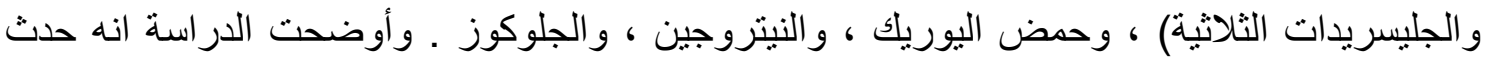

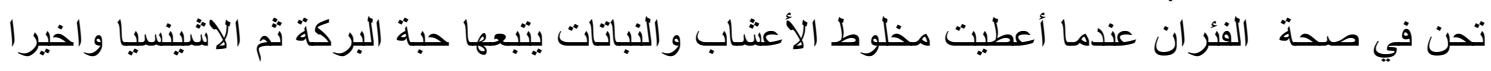

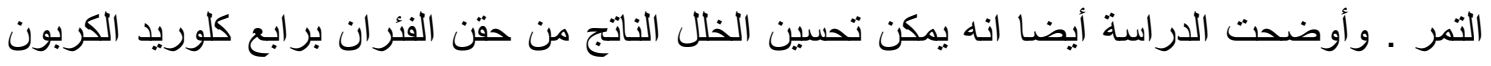
بنسبة 10 \% باستخدام حبة البركة و الاشينسيا و التمر. 


\section{Introduction}

Liver diseases are among the most serious aliment. They may be classified as acute or chronic hepatitis (Inflammatory Liver Diseases), hepatitis (NonInflammatory Diseases) and cirrhosis (degenerative disorder resulting in fibrosis of the liver) (Kumar et al. 2011).

Carbon tetrachloride $\left(\mathrm{CCl}_{4}\right)$ has been widely used in animal models to investigate chemical toxin-induced liver damage.The most remarkable pathological characteristics ofCCl 4 inducedhepatotoxicity are fatty liver, cirrhosis and necrosis (Rencknagel et al. 1989). $\mathrm{CCl}_{4}$ is a well-knownhepatotoxicagent (Ilavarasan et al. 2003). A single dose ofCCl$_{4}(20$ micro $1 / \mathrm{kg})$ induced hepatotoxicity, manifested biochemically by significant elevation of serum enzymes activities, such asalaninetransaminase(ALT), aspartateaminotransferase (AST), and lactate dehydrogenase (LDH) (Mansour, 2000).

Phototherapyis the treatment and prevention of diseases using plants or plants part, such as leaves, flowers, roots, fruits, seeds, and rhizomes. Preparation made from them called medicinal plants, or herbs (Weiss and Fintelmann, 2000). Many plants were suggested to ameliorate or care the liver diseases, among them were the birch, celandine, Dates palm ,dates, rosemary, papaya, onion,Echinacea purpurea and lettuce (Morsi, 1992). Medicinal plants have very important place as they not only maintain the health and vitality of human beings and animals, but also cure several disease, including liver disorders without causing any toxicity (Govind and Madhuri, 2010).

Echinacea purpurea, L. (EP) is one of the most important medical herbs and is a kind of Asteraceae natively perennial grown in North America, which is used pharmacologically and for aesthetic enjoyment.

In2005, (Echinacea)products ranked among the top botanical supplements sold in the United States. Its root and subterranean stem were used by North America in early period to treat trauma and alleviate symptoms of infection and inflammation.

The EP have been proven to show a good immune regulation, anti-inflammation and antioxidant capacity and with no hyper sensitivity or other side effects during clinical trial stages. Varieties of EP all contain similar main ingredients including caffeic acid derivatives, alkamides, flavonoids, essential oils and poly acetylenes and medical activities of which are yet to be exactly identified with corresponding diseases. However, caffeic acid derivatives and alkamides have been proven to be active ingredients with immune regulation effects. Moreover, synergistic antioxdative effect of caffeic acid derivatives, alkamides and polysaccharide fractions was demonstrated by measuring their inhibition of in vitro $\mathrm{Cu}(\mathrm{II})$-catalyzed oxidation of human low-density lipoprotein (LDL) (Lee et al. 1996).

The fruits (Dates) of the date palm (Phoenix dactyliferous, L. ) contain a high percentage of carbohydrates (total sugar from 44 to $88 \%$ ), fat $(0.2-/ 0.5 \%), 15 \%$ salts and minerals, protein $(2.3-5.6 \%)$, vitamins and a high percentage of dietary fiber (6.4-/11.5\%). The flesh of dates contains $0.2-/ 0.5 \%$ oil, whereas the seed 


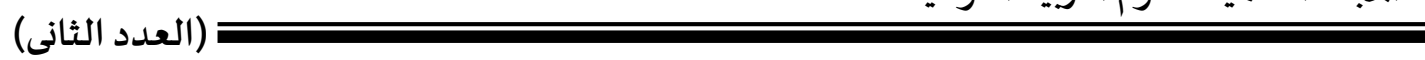

contains from 7.7 to $9.7 \%$ oil. The weight of the seed is $5.6-/ 14.2 \%$ of the date. The fatty acids occur in both flesh and seed as a range of saturated and unsaturated acids, the seeds containing 14 types of fatty acids, but only eight of these fatty acids occur in very low concentration in the flesh. Unsaturated fatty acids include palmitoleic, oleic, linoleic and linoleic acids. The oleic acid content of the seeds varies from 41.1 to $58.8 \%$, which suggests that the seeds of date could be used as a source of oleic acid. There are at least 15 minerals in dates. The percentage of each mineral in dried dates varies from 0.1 to $916 \mathrm{mg} / 100 \mathrm{~g}$ date depending on the type of mineral. In many varieties, potassium can be found at a concentration as high as $0.9 \%$ in the flesh, while it is as high as $0.5 \%$ in some seeds. Other minerals and salts that are found in various proportions include boron, calcium, cobalt, copper, fluorine, iron, magnesium, manganese, potassium, phosphorous, sodium and zinc. Additionally, the seeds contain aluminum, cadmium, chloride, lead and sculpture in various proportions.

Dates contain elemental fluorine that is useful in protecting teeth against decay. Selenium, another element believed to help prevent cancer and important in immune function, is also found in dates. The protein in dates contains 23 types of amino acids, some of which are not present in the most popular fruits such as oranges, apples and bananas. Dates contain at least six vitamins including a small amount of vitamin $\mathrm{C}$, and vitamins B1 thiamine, B2 riboflavin, nicotinic acid (niacin) and vitamin A. The dietary fiber of 14 varieties of dates has been shown to be as high as 6.4-11.5\% depending on variety and degree of ripeness ( Ahmed et al ., 2006).

Nigella sativa seeds contain a complex mixture of more than 100 compounds, some of which have not yet been identified or studied. A combination of volatile oils, fatty acids, flavonoids, saponins, proteins, and trace elements are believed to contribute to its effectiveness. It was found that both the oil and their active ingredients of the seeds, in particular thymoquinone (TQ), possess reproducible anti-oxidant effects through enhancing the oxidant scavenger system, which as a consequence lead to antitoxic effects induced by several insults (Mohamed et al.2010)

The effect of aqueous suspension of Nigella sativa on carbon tetrachloride induced liver damage, CCL4 induced toxicity induced liver damage antagonize aqueous dose of $250-500 \mathrm{mg} / \mathrm{kg}$ suspension of Nigella sativa by raising the level of LDH ( Lactate dehydrogenase) and lowering of Nigella sativa by raising the level of AST (aspartic transaminases) and ALT ( L-alanine amino transfers) 5\% seed of Nigella sativa given to albino mice to evaluate hepatro protective action against dimethyl lami-noaze-benzen induced liver carcinogenesis was studied. The results showed significant changes in the plasma level of alanine (AST) alkaline phosphate ( ALP), total protein and serum albumin which analyzed by malondialdehyde but there is no harmful effect of Nigella sativa on the liver moreover, it exerts hepato protective effect against hepatobiliary carcinogens because of their antioxidant property.So, the present study was carried out to investigate the biological effects ofNigella sativa, Echinacea purpurea, dates 


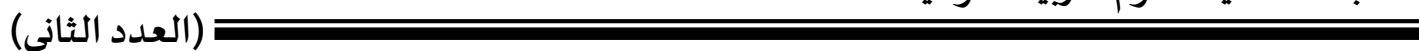

palmand their mixture of the tested plants on serumparameters of liver intoxication in rats. (Mohamed et al ., 2010)

\section{Material and Methods}

\section{Materials}

\section{Plants}

The tested plants were Echinacea purpurea (Cone Flowers) andNigella Sativa ( Black Seeds) which were purchased from herbalist of Cairo, Egypt. Dates palm( Phoenixdactyliferous, L) were purchased from the local markets of Shebin El-kom, MenoufiyaGovernorate, Egypt.

Carbon tetrachloride $\left(\mathrm{CCl}_{4}\right)$ was used as an inducer for liver cirrhosis. It was purchased from El-GomhoryaCompany, Cairo, Egyptas $10 \%$ liquid solution.

\section{Chemical reagents}

Reagent kits were purchased from Diamond Diagnostics (Egypt).

\section{Experimental animals}

Thirty six white male albino rats (weighing about $180 \pm 5 \mathrm{~g}$ ) were used as experimental animals in the present investigation. They were obtained from the Animal House of Research Institute of Ophthalmology, El-Giza, Egypt. They were kept under observation for one week (as adapted period) before the onset of the experiment. The animals were housed in stainless steel cages at normal atmospheric temperature $\left(25 \pm 5^{\circ} \mathrm{C}\right)$ and had a $12 \mathrm{~h}$ light-dark cycle. Food and water were consumed ad libitum.

\section{Methods:}

\section{Induction of liver intoxication in rats}

Thirty six rats were treated subcutaneous injection of carbon tetrachloride in paraffin oil 50\% V/V (2ml/kgb.wt)twice a weekfor two weeks (Jayaserkar et al. 1997).

\section{Preparation ofplant powder}

These plants were washed and dried in drying oven at $50^{\circ} \mathrm{Cfor} 3$ days, then crushed and milled as adried powder.

\section{Animals diet}

The basal diet was prepared according to AIN (1993). The vitamin mixture was prepared according to Campbell (1963), while salt mixture was prepared according to Hegstedet al. (1941).

\section{Experimental design}

Thirty six male albino rats $(180 \pm 5 \mathrm{~g})$ were randomly divided into 6 equal groups (six rats each). All rats were fed on basal diet for one week before starting the experiment for acclimatization. After the adapted period, the mean of initial weight was $205 \pm 5 \mathrm{~g}$. Groups of rats were as the follows:

Group (1): Rats ( $n=6)$ were fed on basal diet only as control negative group. Group (2):Rats $(n=6)$ werekept without any treatment aspositive control group and fed on basal diet after injection with $\mathrm{CCl}_{4}$.

Group (3): Rats $(\mathrm{n}=6)$ were injected by $\mathrm{CCl}_{4}$ then fed on basal diet containing 10\% Cone Flowers(EchinaceaPurpurea) . 
Group (4): Rats $(\mathrm{n}=6)$ were injected by $\mathrm{CCl}_{4}$ then fed on basal diet containing $10 \%$ Black seeds(Nigella sativa).

Group (5): Rats $(\mathrm{n}=6)$ were injected by $\mathrm{CCl}_{4}$ then fed on basal diet containing 10\% Dates palm( Phoenix Dactyliferous, $L$ ).

Group (6): Rats $(\mathrm{n}=6)$ were injected by $\mathrm{CCl}_{4}$ then fed on basal diet containing 15\% of mixture Cone Flowers(Echinacea Purpurea),Black seeds (Nigella sativa) and dates palm ( Phoenix Dactyliferous, L)(5:5:5).

At the end of theexperimental periods (28 days),rats were scarified using diethyl ether anesthesia at fasting state. Part of the blood was taken to determine the level of serum glucose and the other portion of blood samples was collected and allowed tocoagulate at room temperature;other portion of blood was added toit,EDTA (EthyleneDiamineTetra AceticAcid) and centrifuged at 3000r.p.mfor 15 minutes. Serum was carefullyaspirated and transferred into cleancovettubes and stored frozen at $-20^{\circ} \mathrm{Cuntilthe}$ time of analysis.

Biochemical analysis:

SerumAlkaline phosphatase (ALP)was determined according tothe procedure ofIFCC methods.(1983). Aspartateaminotransferase(AST) or (GOT)glutamic oxaloacetictransaminaseandglutamicpyruvictransaminase(GPT)

orAlanineaminotransferase (ALT)werecarried out according to the method of Henry(1974) and Yound (1975). Serum uric acid was determined according to the method described by Fossati et al. (1980).Serum urea in plasma was determined according to the enzymatic method ofPatton and Crouch (1977). Glucose was determined by enzymatic test according toTietz (1976)and Yound (1975).

Enzymatic colorimetric determination of triglycerides was carried out according to Fassati and Prencipe (1982). Total Cholesterol was determined by colorimetric method according to Allain (1974). The determination of HDL was carried out according to the method of Fnedewaid (1972) and Gordonand Amer (1977). The determination of VLDL (very lowdensity lipoproteins) and LDL (low density lipoproteins) was carriedout according to the method of Lee and Nieman (1996).

\section{Statistical Analysis}

Statistical analysis were done using the Statistical Package for the Social Sciences (SPSS for WINDOWS, version 11.0; SPSS Inc, Chicago). Comparative analyses were conducted using the general linear models procedure (SPSS Inc). Values of $\mathrm{P}<0.05$ were considered statistically significant.

\section{RESULTS}

1-Effect of feeding different levels of Black seeds, Cone Flowers andDates palm and their mixture on ALP, AST and ALT levels of $\mathrm{CCl}_{4}$-Intoxicated Rats.

Theresults in Table (1) indicated that mean value of ALP enzyme, rats injected withCCl $\mathrm{Cl}_{4}$ (C +vegroup) was $231.7 \pm 3.4 \mathrm{U} / \mathrm{L}$ while in normal rats $(\mathrm{C}-\mathrm{ve})$ was $98.3 \pm 1.32 \mathrm{ULL}$. These resultsdenote that there was a significant increase in the 
mean value of ALP enzyme of rats poisoned by $\mathrm{CCl}_{4}$ as compared to normal rats. The mean values of (ALP) of diets from groups 3, 4, 5 and 6 were significantly higher than control negative group. Also, it could be noticed that there isnosignificant differences between the values of ALP enzyme of groups 4 and 5 . Meanwhile, rats given $\mathrm{CCl}_{4}$ then fed on diet of group 6 (rats fed on basal diet with $15 \%$ plant and herbs mixture ) showed the lowest mean value in ALP enzyme level in the serum, which it was $208 \pm 13.1 \mathrm{UL}$ as compared to control positive group and recorded the best result of all treatments. It could be observed that due to intoxicate rats the serum levels of ASTin Table (1)showed a significant increase in control positive group as compared to normal rats represents 38.25 \pm 5.82 and $22.06 \pm 1.07 \mathrm{U} / \mathrm{L}$, respectively. There is nosignificantdifferences between groups 5and control positive group. Also, there is no significant differences between groups 3 and 6. Meanwhile, group 6 (rats fed on basal diet with $15 \%$ mixture ) showed the lowest level in serum AST and recorded the best results as compared to all treatments.

For ALT,in rats givenCCl $\mathrm{Cl}_{4}$ then fed on all treatments, groups 3, 4, 5 and 6 wereshowing a significant differences when compared to controlnegative group . There is significantdifference between group (5) and control positive group. Also,there isno significantdifference between groups 3 and 4 . The obtained results showed that there isno significantdifference in serum levels of ALT in group 6 as compared to normal rats and the best treatment was recorded for group 3 (rats fed on basal diet with $10 \%$ date palm.

Table (1):Effect of feeding different levels of Dates palm, Echinacea purpurea , Nigella sativa and their mixture on ALP, AST and ALT(U/L) at the levels of $\mathrm{CCl}_{4}$-Intoxicated

\begin{tabular}{|c|c|c|c|}
\hline Liver function & \multirow{2}{*}{$\begin{array}{l}\text { ALP } \\
\text { Mean } \pm \text { SD }\end{array}$} & \multirow{2}{*}{$\begin{array}{l}\text { AST } \\
\text { Mean } \pm \text { SD }\end{array}$} & \multirow{2}{*}{$\begin{array}{l}\text { ALT } \\
\text { Mean } \pm \text { SD }\end{array}$} \\
\hline Animal Groups & & & \\
\hline $\begin{array}{l}\text { Group (1) } \\
\text { Control - ve }\end{array}$ & $98.3 \pm 1.3^{\mathrm{E}}$ & $22.06 \pm 1.07^{\mathrm{D}}$ & $9.51 \pm 0.95^{\mathrm{D}}$ \\
\hline $\begin{array}{l}\text { Group (2) } \\
\text { Control + ve }\end{array}$ & $231.7 \pm 3.4^{\mathrm{A}}$ & $38.25 \pm 5.82^{\mathrm{A}}$ & $17.10 \pm 1.1^{\mathrm{A}}$ \\
\hline $\begin{array}{l}\text { Group (3) } \\
\text { 10\%Dates palm }\end{array}$ & $228.3 \pm 5.0^{\mathrm{A}}$ & $29.66 \pm 1.76^{\mathrm{B}}$ & $13.29 \pm 0.2^{\mathrm{C}}$ \\
\hline $\begin{array}{l}\text { Group (4) } \\
10 \% \text { Echinacea purpurea }\end{array}$ & $223.3 \pm 7.5^{\mathrm{B}}$ & $38.52 \pm 7.23^{\mathrm{A}}$ & $16.93 \pm 1.2^{\mathrm{A}}$ \\
\hline $\begin{array}{l}\text { Group (5) } \\
10 \% \text { Nigella sativa }\end{array}$ & $220.7 \pm 2.0^{\mathrm{B}}$ & $36.10 \pm 4.93^{\mathrm{A}}$ & $15.43 \pm 1.2^{\mathrm{B}}$ \\
\hline $\begin{array}{l}\text { Group (6) } \\
15 \% \text { mixture of tested plant and } \\
\text { herbs }\end{array}$ & $208.1 \pm 3.1^{C}$ & $32.12 \pm 0.52^{\mathrm{B}}$ & $15.80 \pm 0.4^{\mathrm{B}}$ \\
\hline
\end{tabular}


2- Effect of feedingon Dates palm,Echinacea purpurea, Nigella sativa and their mixture on total cholesterol and triglyceride $(\mathrm{mg} / \mathrm{dl})$ at the levels of $\mathrm{CCl}_{4}$ intoxicated rats.

Data in Table (2)revealed thatInjection ofCCl 4 led to a significant $(\mathrm{P} \leq 0.05)$ increased serum total cholesterol level inhepatotoxicrats. The mean value \pm SDof serum cholesterol inhepatotoxicgroupcontrol(+ve) was $173.55 \pm 12.38 \mathrm{mg} / \mathrm{dl}$ compared to $79.78 \pm 5.25 \mathrm{mg} / \mathrm{dl}$ in the control(-ve)group. The mean values of total cholesterol in rats givenCCl $\mathrm{Cl}_{4}$ then fed on all diets of groups $3,4,5$ and 6 were significantly lower than positive controlgroup .There is no significantdifferences in total cholesterol between groups 3and 5 . Concerning triglycerides(Table 2), data revealed that rats injected withCCl $\mathrm{Cl}_{4}$ (control positive group) had higher value $(\mathrm{P} \leq 0.05)$ of triglycerides compared to normal ratscontrol negative group. There werenon-significantdifferences between groups 3 and 5. Meanwhile, group 6 (rats fed on diet contained 15\% mixture) showed the lowest level in the mean value of serum triglycerides, which showed $70.10 \pm 0.92 \mathrm{mg} / \mathrm{dl}$ as compared to all treatments and recorded the best result.

Table (2):Effect of feedingonDates palm, Echinacea purpurea, Nigella sativa and their mixture on total cholesterol and triglyceride levels $(\mathrm{mg} / \mathrm{dl})$ of $\mathbf{C C l}_{4}$ intoxicated rats.

\begin{tabular}{|l|l|l|}
\hline \multirow{2}{*}{ Animal Groups } & \multicolumn{2}{|c|}{ Lipid Fraction } \\
\cline { 2 - 3 } & $\begin{array}{l}\text { Total cholesterol } \\
\text { Mean } \pm \text { SD }\end{array}$ & $\begin{array}{l}\text { Triglyceride } \\
\text { Mean } \pm \text { SD }\end{array}$ \\
\hline $\begin{array}{l}\text { Group (1) } \\
\text { Control - ve }\end{array}$ & $79.78 \pm 5.25^{\mathrm{F}}$ & $40.40 \pm 0.96^{\mathrm{G}}$ \\
\hline $\begin{array}{l}\text { Group (2) } \\
\text { Control + ve }\end{array}$ & $173.55 \pm 12.38^{\mathrm{A}}$ & $111.70 \pm 3.11^{\mathrm{A}}$ \\
\hline $\begin{array}{l}\text { Group (3) } \\
\text { 10\%Dates palm }\end{array}$ & $152.29 \pm 6.92^{\mathrm{C}}$ & $92.30 \pm 1.44^{\mathrm{C}}$ \\
\hline $\begin{array}{l}\text { Group (4) } \\
\mathbf{1 0 \%} \text { Echinacea pupurea }\end{array}$ & $152.12 \pm 4.71^{\mathrm{E}}$ & $71.00 \pm 2.85^{\mathrm{D}}$ \\
\hline $\begin{array}{l}\text { Group (5) } \\
\text { 10\% Nigella sativa }\end{array}$ & $155.31 \pm 6.15^{\mathrm{C}}$ & $97.00 \pm 2.85^{\mathrm{C}}$ \\
\hline $\begin{array}{l}\text { Group (6) } \\
\text { 15\% mixture of tested plant } \\
\text { and herbs }\end{array}$ & $137.08 \pm 1.04^{\mathrm{D}}$ & $70.10 \pm 0.92^{\mathrm{D}}$ \\
\hline
\end{tabular}

Non- significant differences between the values had the same letter.(Significance at $\mathbf{p} \leq \mathbf{0 . 0 5}$ ). 
3- Effect of feeding onDates palm, Echinacea purpurea,Nigella sativaand their mixture on HDL-c, LDL-c, VLDL-c and the ratio between LDL-c/ HDL-c (mg/dl) levels of $\mathrm{CCl}_{\mathbf{4}}$-intoxicated rats.

It is obvious that rats injected with $\mathrm{CCl}_{4}$ (control + ve) give the mean valueof serum levels HDL-c was $29.38 \pm 5.3 \mathrm{mg} / \mathrm{dl}$. In normal rats (control $-\mathrm{ve}$ ) the mean value of serum levels the HDL-c was $61.58 \pm 3.6 \mathrm{mg} / \mathrm{dl}$ in Table (3). These finding denote that there was a significant decrease in HDL-c in the serum of rats poisoned by $\mathrm{CCl}_{4}$ as compared to normal rats .There werenon-significant differences between rats given $\mathrm{CCl}_{4}$ then fed on diets of groups 3, 5 and 6 . Finally group 6(rats fed on diet contained $15 \%$ mixture ) showed the highest increase in serum level of HDL-c and recorded the best treatment. It could be noticed that the datain Table 3 evidence that, LDL-c levels was significantly elevated in control positive group to $105.03 \pm 8.0$ from $21.86 \pm 2.7 \mathrm{mg} / \mathrm{dl}$ in control negative group. All rats intoxicated with $\mathrm{CCl}_{4}$ then fed on all tested plant materials showed significant decrease in LDL-c as compared to control positive group. Group 4 (rats fed on diet contained 10\% Echinacea purpurea ) showed the lowest value of serum LDL-c and recorded the best result as compared to all treatments. Data presented in Table(3) indicated the effect of feeding $\mathrm{CCl}_{4}$ intoxicated rats with dates palm, Cone flowers, and Black seedson the serum levels of VLDL-c.

There weresignificantdifferences between group 6 and negative control group. Group 4 (rats fed on diet contained 10\%Echinacea purpurea)showed the lowest decrease in serum level of VLDL-c and recorded the best results as compared to all groupsin Table 3. As regards to rats injected with $\mathrm{CCl}_{4}$ without treatment (controlpositive ), the serum LDL-c/HDL-c increased dramatically from $0.35 \pm$ 0.04 for control negative group to $3.67 \pm 1.03$ for control positive group.Rats fed on basediet contained 10\% Echinacea purpureashowed the lowest level in the serum LDL-c/HDL-c and recorded the best result as compared to all treatments.

Table (3): Effect of feeding onDates palm, Echinacea purpurea, Nigella sativa and their mixture on HDL-c, LDL-c, VLDL-c and the ratio between LDL-c/ HDL-c (mg/dl) levels of $\mathrm{CCl}_{4}$-intoxicated rats.

\begin{tabular}{|c|c|c|c|c|}
\hline $\begin{array}{c}\text { Lipid fraction } \\
\text { Animal Groups }\end{array}$ & $\begin{array}{c}\text { HDL-C } \\
\text { Mean SD }\end{array}$ & $\begin{array}{c}\text { LDL-C } \\
\text { Mean SD }\end{array}$ & $\begin{array}{c}\text { VLDL-C } \\
\text { Mean SD }\end{array}$ & $\begin{array}{c}\text { LDL- } \\
\text { C/HDL-C } \\
\text { Mean SD }\end{array}$ \\
\hline $\begin{array}{c}\text { Group (1) } \\
\text { Control - ve }\end{array}$ & $61.58 \pm 3.6^{\mathrm{A}}$ & $21.86 \pm 2.7^{\mathrm{H}}$ & $8.92 \pm 0.19^{\mathrm{E}}$ & $0.35 \pm 0.04^{\mathrm{G}}$ \\
\hline $\begin{array}{c}\text { Group (2) } \\
\text { Control + ve }\end{array}$ & $29.38 \pm 5.3^{\mathrm{E}}$ & $105.03 \pm 8 .^{\mathrm{A}}$ & $23.20 \pm 0.6^{\mathrm{A}}$ & $3.67 \pm 1.03^{\mathrm{A}}$ \\
\hline $\begin{array}{c}\text { Group (3) } \\
\text { 10\% Dates palm }\end{array}$ & $51.05 \pm 4.0^{\mathrm{C}}$ & $63.97 \pm 8.4^{\mathrm{D}}$ & $12.42 \pm 0.9^{\mathrm{D}}$ & $1.26 \pm 0.22^{\mathrm{C}}$ \\
\hline $\begin{array}{c}\text { Group (4) } \\
\text { 10\% Echinacea } \\
\text { purpurea }\end{array}$ & $53.46 \pm 1.0^{\mathrm{C}}$ & $46.67 \pm 0.6^{\mathrm{F}}$ & $9.08 \pm 0.38^{\mathrm{E}}$ & $0.86 \pm 0.12^{\mathrm{E}}$ \\
\hline $\begin{array}{c}\text { Group (5) } \\
\text { 10\% Nigella sativa }\end{array}$ & $53.03 \pm 4.16^{\mathrm{C}}$ & $58.88 \pm 8.5^{\mathrm{E}}$ & $9.86 \pm 0.28^{\mathrm{E}}$ & $1.11 \pm 0.26^{\mathrm{D}}$ \\
\hline $\begin{array}{c}\text { Group (6) } \\
\text { 15\%mixture of } \\
\text { plant and herbs } \\
\text { mixture }\end{array}$ & $50.55 \pm 1.64^{\mathrm{C}}$ & $84.30 \pm 3.7^{\mathrm{B}}$ & $14.16 \pm 0.7^{\mathrm{C}}$ & $1.68 \pm 0.13^{\mathrm{B}}$ \\
\hline
\end{tabular}


Non-significant differences between the values had the same letter.Significance at $\mathbf{p} \leq \mathbf{0 . 0 5}$.

4- Effect of feeding onDates palm, Echinacea purpurea, Nigella sativa and their mixture on glucose(mg/dl) at the different levels of CCl4 intoxicated rats.

It could be observed that, the mean value $\pm \mathrm{SD}$ of glucosein Table (4)of control positive group significantly increased, as compared to normal rats, it was being $141.14 \pm 0.02$ and $81.05 \pm 2.11 \mathrm{mg} / \mathrm{dl}$, respectively. In rats given $\mathrm{CCl}_{4}$ then fed on all treatments, there were significant increases in the glucose levels as compared to normal group which were $126.79 \pm 0.72,131.13 \pm 0.21,131.12 \pm 0.85$ and $118.14 \pm 0.59 \mathrm{mg} / \mathrm{dl}$ for groups 3, 4, 5 and 6, respectively. There isno significantdifference between groups 3,4 and 5. Finally, group 6 (rats fed on diet contained $15 \%$ mixture ) showed the lowest increase in glucose level which was $118.14 \pm 0.59 \mathrm{mg} / \mathrm{dl}$ and recorded the best treatment.

Table (4):Effect of feeding onDates palm,Echinacea purpurea, Nigella sativa and their mixtureon glucose $(\mathrm{mg} / \mathrm{dl})$ at the different levels of CCl4 intoxicated rats.

\begin{tabular}{|l|c|}
\cline { 2 - 2 } \multicolumn{1}{c|}{ Animal Groups } & \multicolumn{1}{c|}{$\begin{array}{c}\text { Glucose } \\
\text { (mg/dl) } \\
\text { Mean } \pm \text { SD }\end{array}$} \\
\hline $\begin{array}{l}\text { Group (1) } \\
\text { Control - ve }\end{array}$ & $81.05 \pm 2.11^{\mathrm{D}}$ \\
\hline $\begin{array}{l}\text { Group (2) } \\
\text { Control + ve }\end{array}$ & $141.14 \pm 0.02^{\mathrm{A}}$ \\
\hline $\begin{array}{l}\text { Group (3) } \\
\mathbf{1 0 \%} \text { Dates palm }\end{array}$ & $126.79 \pm 0.72^{\mathrm{B}}$ \\
\hline $\begin{array}{l}\text { Group (4) } \\
\mathbf{1 0 \%} \text { Echinacea purpurea }\end{array}$ & $131.13 \pm 0.85^{\mathrm{B}}$ \\
\hline $\begin{array}{l}\text { Group (5) } \\
\mathbf{1 0 \%} \text { Nigella sativa }\end{array}$ & $131.12 \pm 0.85^{\mathrm{B}}$ \\
\hline $\begin{array}{l}\text { Group (6) } \\
\mathbf{1 5 \%} \text { mixture of plant and herbs }\end{array}$ & $118.14 \pm 0.59^{\mathrm{C}}$ \\
\hline
\end{tabular}

Non-significant differences between the values had the same letter. Significance at $\mathbf{p} \leq \mathbf{0 . 0 5}$

5- Effect of feeding onDates palm, Echinacea purpurea,Nigella sativa and their mixture on Uric acid and Urea nitrogen $(\mathrm{mg} / \mathrm{dl})$ at the different levels of $\mathrm{CCl}_{4}$ intoxicated rats.

Results revealed that, treated rats with $\mathrm{CCl}_{4}$-intoxicated diet controlpositivegroup led to a significant increase $(\mathrm{P} \leq 0.05)$ in serum uric acid when compared with controlnegative group. The mean values of uric acid of groups 4, 5 and 6 were significantly lower than positive controlgroup (Table 
5).Non-significantdifferences were observed between groups 3 and controlpositivegroup. Meanwhile, group 6 (rats fed on diet contained 15\% mixture of all plant materials) showed the lowest level in serum uric acid among all treatments and recorded the best result as compared to normal group .

For urea nitrogen,there isnon-significantdifference between group 3 and controlpositivegroup. Group 6 showed lower $(\mathrm{P} \leq 0.05)$ in urea nitrogen than both control groups. Finally, group 6 (rats fed on basal diet with 15\% mixture of all plant materials) showed the lowest level of urea nitrogen among all treatment groups.

Table (5):Effect of feeding onDates palm ,Echinacea purpurea, Nigella sativa and their mixture on Uric acid and Urea nitrogen(mg/dl) at the different levels of $\mathrm{CCl}_{4}$ intoxicated rats.

\begin{tabular}{|c|c|c|}
\hline Kidney function & \multirow{2}{*}{$\begin{array}{c}\text { Uric acid } \\
\text { (mg/dl) } \\
\text { Mean } \pm \text { SD }\end{array}$} & $\begin{array}{c}\text { Urea Nitrogen } \\
\text { (mg/dl) } \\
\text { Mean } \pm \text { SD }\end{array}$ \\
\hline $\begin{array}{c}\text { Group (1)Control - } \\
\text { ve }\end{array}$ & $1.05 \pm 0.1^{\mathrm{C}}$ & $14.7 \pm 0.9^{\mathrm{B}}$ \\
\hline $\begin{array}{c}\text { Group (2)Control }+ \\
\text { ve }\end{array}$ & $1.14 \pm 0.1^{\mathrm{A}}$ & $15.6 \pm 2.2^{\mathrm{A}}$ \\
\hline $\begin{array}{c}\text { Group (3)10\%Dates } \\
\text { palm }\end{array}$ & $1.13 \pm 0.1^{\mathrm{A}}$ & $15.6 \pm 1.4^{\mathrm{A}}$ \\
\hline $\begin{array}{c}\text { Group(4)10\% Echina } \\
\text { cea purpurea }\end{array}$ & $1.12 \pm 0.0^{\mathrm{B}}$ & $13.6 \pm 1.9^{\mathrm{C}}$ \\
\hline $\begin{array}{c}\text { Group } \\
\text { (5)10\% Nigella sativa }\end{array}$ & $1.11 \pm 0.10^{\mathrm{B}}$ & $13.8 \pm 0.9^{\mathrm{C}}$ \\
\hline $\begin{array}{c}\text { Group } \\
\text { (6)15\% mixture of } \\
\text { plant and herbs }\end{array}$ & $0.79 \pm 0.7^{\mathrm{E}}$ & $10.1 \pm 1.2^{\mathrm{E}}$ \\
\hline
\end{tabular}

\section{Non-significant differences between the values had the same}

\section{letter.Significance at $\mathbf{p} \leq \mathbf{0 . 0 5}$.}

The reactive electrons species from $\mathrm{CCl}_{4}$ induces rat liver cirrhosis that resembles the human disease, and it can serve as a suitable animal model for studying human liver cirrhosis (An et al. 2006).

Toxicity experienced by the liver during $\mathrm{CCl}_{4}$ poisoning results from the production of a metabolite, $\mathrm{CCl}_{4}$ which is a direct hepatotoxic responsible for change in cell permeability and it inhibits mitochondrial activity followed by cell death (Ambrose et al. 2009). It has also been reported that chronic $\mathrm{CCl}_{4}$ exposure produced cirrhosis in rats (Chieli and Malvadi, 2008).

An obvious sign of hepatic injury is the leakage of cellular enzyme into plasma (Schmidt et al. 1975). When the liver cell plasma membrane is damaged, a variety of enzymes normally located in the cytosol are released into blood stream. Their estimation in the serum is a useful quantitative marker for the extent and type of hepatocellular damage (Ansari et al. 1991). ALT and AST are the most often used and most specific indicators of hepatic injury and represent 
markers of hepatocellular necrosis. These liver enzymes catalyze transfer of alpha- amino group aspartate and alanine to the alpha-ketoglutaric acid.

Whereas ALT is primarily localized to the liver, AST is present in a wide variety of tissue, including heart, skeletal, kidney, brain, and liver. AST is present in both the mitochondria and cytosol of hepatocytes, but ALT is found only in the cytosol. In an asymptomatic person with isolated elevation of AST or ALT level, diagnostic clues can be garnered from the degree of elevation (Rosen and Keeffe, 1998).

Results of the current study revealed that administration of $\mathrm{CCl}_{4}$ caused significant increases the levels ofaspartateaminotransferase,alanineaminotransferase,glucose levels, lipid profileandkidney enzymesand these are in agreement withTúnezet al.(2005). On the other hand, the current study demonstrated that the treatment with Cactus pear extract caused a marked ameliorations oftransaminaseenzymes activity (ALT and AST). The results are in accordance withTapieroet al.(2002)who showed the effect of Echinacea purpureaextractson carbon tetrachloride-induced hepatotoxicity in rats.

The mechanism by which the Cactus pear fruit induces its hepatoprotective activity is not certain. However, it is possible that $\beta$-sit sterol, a constituent of cactus pear, which is at least partly responsible for the protective activity against $\mathrm{CCl}_{4}$ hepatotoxicity (Tesoriere et al., 2004). An additional and important factor in the hepatoprotective activity of any drug is the ability of its constituents to inhibit the aromatase activity of cytochrome P-450, thereby favoring liver regeneration. On that basis, it is suggested that flavonoids in Cactus pear could be a factor contributing to its hepatoprotective ability through inhibition of cytochrome P-450 aromatase (Kowalska et al. 1990). In addition, the recorded content of vitamin $\mathrm{C}$ in dates palm (35 -38 $\mathrm{mg}$ per $100 \mathrm{~g}$ ) may also play a role in hepatoprotection. Previous in vivo studies indicate that hepatic microsomal drug metabolism decreases in ascorbic acid deficiency and is augmented when high supplements of the vitamin are given to guinea pigs (Burtis and Ashwood, 2001).

Blood glucose concentration is known to depend on the ability of the liver to absorb or produce glucose. The liver performs its glucostatic function owing to its ability to synthesize or degrade glycogen according to the needs of the organism, as well as via gluconeogenesis (Ahmed et al., 2006). The blood sugar level after overnight fasting in cirrhotic patients is believed to decrease only in severe hepatic failure (Kruszynskaand McIntyre, 1991). This is confirmed by the obtained data that indicate that glucose levels in cirrhosis decreased.

\section{Conclusions}

The study clearly demonstrates that $15 \%$ of tested plant and herbs mixture have potential for treatment and prevention of $\mathrm{CCl}_{4} \varepsilon$-induced hepatic cytotoxicity. This study, along with other research, targets mixture as a potentially safe and effective plant and herbs that has important medicinal values and benefits. 


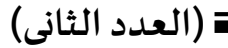

\section{References}

Ahmed, O.M.; Abdel Hamid, H.; Bastway, M. and Hasona, N.A. (2006).Antihyperglycemic effects of Cactus pear and Echinacea purpurea $s$ aqueous extract in diabetic and hypercholesterolemiarats. J. Egypt. Ger. Soc. Zool., 51A: 371-393.

AIN, (1993).American Institute of purified Diet for Laboratory Rodent, Final Report. J. Nutr., 123: 1939- 1951.

Allain, C. (1974).Cholesterol Enzymatic colorimetric Method. J. Clin. Chem., 20:470.

Ambrose, A. M.; DeEds, F. and Rather, L. J. (2009).Further studies on toxicity of $\mathrm{CCl} 4$ in rats. Proceedings of Society of Experimental and Biological Medicine, 74: 134-140.

An, J. H.;Seong,J.; Oh, H.; Kim, W.; Han, K. H. and Paik, Y. H. (2006):"Protein expression profiles in a rat cirrhotic model induced byCCl $\mathrm{Cl}_{4}$. Korean J .Hepatol., 12: 93-102.

Ansari, R. A.; Tripathi, S. C.; Patnaik, G. K. and Dhawan, B. N. (1991).Antihepatotoxic properties of picroliv, an active fraction from rhizomes of Picrorhizakurroa. J. Ethnopharmacol., 34: 61-68.

Burtis, C.A. and Ashwood, E.R. (2001).Tietz's Fundamentals of Clinical Chemistry. WB Saunders, Philadelphia. 565.

Campbell, J. A. (1963).Methodology of protein evaluation R. A. G.Nutr. Document R. 10 Led. 37: June Meeting. New York.

Chieli, E. and Malvadi, G. (2008). Role of Cyt P-450 dependent and FAA containing mono oxygenases in the bio activation of Thioacetamideand $\mathrm{CCl}_{4}$, thiobezamide and their sulphoxides.Biochem.Pharmacol., 34: 395-396.

Fassati, P. and Prencipe, L. (1982).Triglyceride Enzymatic Colorimetric Method. J. Clin. Chem., 28:2077.

Fnedewaid, W.T. (1972).Determination of HDL.Clin. Chem., 8:499.

Fossati, P; Prencipe, L. and Berti, G. (1980). Use of 3.5- dichloro- $\mathrm{Z}^{-}$ hydroxybenzenesulfonic acid/4 aminophenazone chromogenic systems in direct enzymic assay of uric acid in serum and urine. Clin. Chem., 26:227-231.

Gordon, T. and Amer, M. (1977). Determination of HDL. J. Med., 62:707.

Govind, P. and Madhuri, S. (2010).Significance of fruits and vegetables in malnutrition cancer. PL Arch 10(2): 517-522.

Hegsted, D.; Mills, R. and Perkins, E. (1941).Salt Mixture. J. Biol. Chem., 138:459.

Henry, R. J. (1974):"Clinical Chemistry Principles and Techniques". $2^{\text {nd }} E D$. , Harper and publisher, New York, Philadelphia.

IFCC. (1983). Methods for measurement of catalytic concentration of Enzymes, parts 5: IFCC, methods for alkaline phosphatase. J. Clin. Chem. ClinBiochem., 21:731-748.

Ilavarasan, R.; Vasudevan, M.; Anbazhagan, S. and Venkataraman, S. (2003): Antioxidant activity ofthespesiapopulnea bark extracts against carbon tetrachloride-induced liver injury in rats". J. Ethnopharmacol., 87: 227-230.

Jayasekhar, P.; Mohanan, P.V. and Rahinam, K. (1997)Hepatoprotective activity of ethyl acetate extract of Acacia catechu. Indian. J. Pharmacology, 29:426-428. 
Kowalska, D.P.; Feeley, R.M. and Jones, D.P. (1990)Use of exogenous glutathione for metabolism of peroxidized methyl linoleate in rat small intestine. J. Nutr., 120: 1115-1121.

Kruszynska, Y.T. and McIntyre, N. (1991)Carbohydrate metabolism. In: McIntyre, N.; Benhamou, P.J.; Bircher, J.; Rizzetto, M. and Rodes, J. (Eds.) Oxford Textbook of Clinical Hepatology. Oxford University Press, Oxford. 129-143.

Kumar, C. H.; Ramesh, A.; Kumar, J. N. and Mohammed, I. B. (2011)A Review on hepatoprotective activity of medicinal plants, IJPSR, 2 (3): 501-515.

Lee, R. D. and Nieman, D. C. (1996) . Nutritional Assessment. $2^{\text {nd }}$ ED. Mosby, Missoun, USA.

Mansour, M. A. (2000).Protective effects of thymoquinone and deferrio-xamine against hepatotoxicity of carbon tetrachloride in mice. Life Sci, 66(26): 25832591.

Morsi, A. E. (1992). Your Health and Healing between your Hands in Herbs.In Arabic, Egypt.

Mohamed, H. A.I .H.; El Sayed , M. and Moawad .(2010). Protective Effect Of Nigella Sativa Seeds Against Dimethyl AminoazoBenzene (DAB) Induced Liver Carcinogenesis" . Nature and science .8(6).

Patton, C. and Crouch, S. (1977).Determination of serum urea Enzymatically Anal.Chem., 49.

Recknagel, R. O.; Glende, E. A.; Dolak, J. A. and Waller, R. L. (1989).Mechanism of Carbon-tertrachloride Toxicity. Pharmacology Therapeutics, 43 (43): 139-154.

Rosen, H. R. and Keeffe, E. B. (1998).Laboratory evaluation of the patient with signs and symptoms of liver disease. In: Brandt LJ. (Ed.) Clinical Practice of Gastroenterology. Vol 2, Churchill Livingstone, Philadelphia, 812-20.

Schmidt, E.; Schmidt, F. W.; Mohr, J.; Otto, P.; Vido, I.; Wrogeman, K.andHerfarth, C. (1975). Liver Morphology and enzyme release. Further studies in the isolated perfused rat liver. In: Keppler (Ed.) Pathogenesis and Mechanism of Liver Cell Necrosis. Medical and Technical Publishing Co. Ltd., Lancaster. 147.

Tapiero, H.; Tew, K. D.; Ba, G. N. and Mathe, G. (2002).Polyphenols: Do they play a role in the prevention of human pathologies? Biomed Pharmacother.,56: 200-207.

Tesoriere, L.; Butera, D.; Pintaudi, A. M.; Allegra M. and Livrea M. A. (2004). Supplementation with cactus pear (Opuntiaficus-indica) fruit decreases oxidative stress in healthy humans: a comparative study with vitamin C. Am. J .Clin. Nutri., 80: 391-395 .

Tietz, N.W. (1976).Fundamentals of Clinical Chemistr. Philadelphia, W.B. Saunders. P243.

Túnez, I.; Carmen Muñoz, M.; Villavicencio, M. A.; Medina, F. J.; de Prado, E. P.; Espejo, I.; Barcos, M.; Salcedo, M.; Feijóo, M. and Montilla, P.(2005). Hepato- and neurotoxicity induced by Thioacetamide and $\mathrm{CCl} 4{ }_{4}$ Protective effects of melatonin and dimethylsulfoxide. Pharmacol. Res., 52: 223-228.

Weiss, R. F. and Fintelmann, V. (2000).Herbal Medicine $2^{\text {nd }}$ ED., Georg ThiemeVerlag, New York.

Yound, D. S. (1975). Determination of GOT. Clin.Chem., 21. 